\title{
Teacher Perspective on Integrating ICTs into Teaching of Art in the Colleges of Education in Ghana
}

\author{
AHETO-DOMI BRAIN $^{1 *} \quad$ SUMAILA ISSAH $^{2} \quad$ EBENEZER K. ACQUAH, PHD ${ }^{3}$ \\ 1.Peki College of Education, Department of Technical and Vocational Education, P. O. Box 14, Peki - Volta \\ Region Ghana \\ 2.Bia Lamplighter College of Education, Sefwi Debiso Department of Creative Arts, P. O. Box 97 , \\ Sefwi -Debiso, Ghana \\ 3.University of Education, Winneba Department of Graphic Design, P. O. Box 25, Winneba - Ghana
}

\begin{abstract}
This paper is one of the discourse that holistically evaluate the perspectives of tutors in integrating ICTs into their teaching. There is universal recognition of the need to use information and communication technology (ICT) in education as we are in the era of globalization where the free flow of information via satellite and the internet holds power in global information dissemination of knowledge. The study investigated the pedagogical underpinnings of ICTs in education in the colleges of education in Ghana against the 21st century teaching utilized both qualitative and quantitative methods. Findings indicated that majority of the respondents agreed that the colleges use variety of teaching methods and again few tutors of Arts employ technology to their advantage in making sure that students understand concepts they impart through the appropriate means. The study conjectures that currently, there is a slight mix in the colleges of education as many of the members of the colleges lack that technical support and know-how, impeding professional development on how to integrating ICTs into their teaching.
\end{abstract}

Keywords: ICTs, ICT Tools, Technology, Tutor, Student-teachers, Perception, Education

DOI: $10.7176 / \mathrm{ADS} / 77-02$

Publication date:October $31^{\text {st }} 2019$

\subsection{Introduction and Background}

The 1998 UNESCO World Education Report, Teachers and Teaching in a world, describes the radical implications ICTs have for conventional teaching and learning. It predicts the transformation of the teachinglearning process and the way teachers and learners gain access to knowledge and information. With the emerging new technologies, the teaching profession is evolving from an emphasis on teacher-centered, lecture-based instruction to student-centered, interactive learning environments. Teacher education institutions to day should develop skills taking into consideration the technology pedagogy and content knowledge (TPACK Model) so as to assume a leadership role in the transformation of education or be left behind in the swirl of rapid technology change. For education to reap the full benefits of ICTs in learning, it is essential that teachers are able to effectively use these new tools for learning. Teacher education institutions and programmers must provide the leadership for pre-and in-service for teachers and model the new pedagogies and tools for learning (Resta and Semenov 2002).

The role of technology in teaching is rapidly becoming one of the most important and widely discussed issues in contemporary education policy (Rosen and Well, 1995; and Thierer 2000 cited in Aduwa-Ogiegbaen and Iyamu 2005). Most experts in the field agreed that, when appropriately used, information and communication technology hold great promise to improve teaching and learning in addition to shaping workforce opportunities. (Poole cited in Aduwa-Ogiegbaen and Iyamu 2005), has indicated that computer literacy is now regarded as the new illiteracy. This has actually gingered personnel's new and strong desire to equip schools with computer facilities and qualified personnel necessary to produce technologically proficient and efficient students in developed and developing countries of the world. There is no doubt that ICTs can aid the instructional process and facilitate students' learning.

Many students have found positive effect associated with technology aided instruction (Burnett, Fitzgerald and Warner, cited in Aduwa-Ogiegbaen and Iyamu 2005). In the more advanced industrialized nations, there has been a staggering amount of research and publication related to ICTs use for educational purposes during the past decade. Today, nearly everyone in the industrialized nations gained access to ICTs and the purchase of computers for school use in such nations as the United States has been increasing in such a pace that it's difficult to keep track of how many computer machines are now in American schools (Harper, cited in Aduwa-Ogiegbaen and Iyamu 2005). Becker (cited in Aduwa-Ogiegban and Iyamu 2005) chronicled a comprehensive survey of the instructional uses of computers in United States public and non-public schools. The report suggested that over one million computers were used during 1985. The report also says half-a million teachers used computer during the same period and then half of U.S secondary schools (about 16,500 schools) owned 15 or more computers. Also, over 7500 elementary schools owned over 15 or more computers. It has been almost two decades since the 
figures quoted above were released. There is no doubt that those figures would have increased tremendously since then. Bergheim and Chin (cited in Aduwa-Ogiegbaen and Iyamu 2005) observed that the U.S government made available $\$ 529$ million to schools out of which 60 to 70 percent was spent on computer education. However, in the U.S administration's fiscal budget for 2001, more than $\$ 900$ million was earmarked for educational technologies (Hess and Leal, 2001). This study sought to examine teacher perspectives on integrating ICTs into subject teaching in the colleges' education in Ghana.

\subsection{Research Questions}

1. How are the current approaches to ICTs in the Colleges of Education towards a transformation in the teaching and learning process?

2. Do tutors integrate $21^{\text {st }}$ century teaching and learning skills (i.e the use of ICTs) in the course taught?

3. What is the level of ICT integration readiness among teachers and students of the Colleges of Education in Ghana?

\subsection{Conceptual framework}

Two communication theories support the perspectives of this study in the context under review among other theories that would have equally shared similar perspectives. They are "Uses and Gratifications Theory" because it is one of the theories that "seeks to focus on why people use certain media rather than on the content. The researchers adopted the "Uses and Gratifications Theory", also called "Needs and Gratifications Theory". The named theory is a model that focuses on why people use certain media rather than on the content. According to Severin \& Tankard (2001), the uses and gratifications theory involves a shift of focus from the purposes of the communicator to the purposes of the receiver to determine what functions mass communication is serving for audience members. One of the tenets of the uses and gratifications theory is that audiences are active, and they seek to find out the mass media that satisfy their gratifications. The Internet has enabled audience to find and also have more options from which they are able to select the websites and web pages that satisfy their specific needs.

Uwem, Enobong, and Nsikan, (2013) assert that while using the new media, people are actively combining several motives to fulfill their yearnings and aspirations, properly referred to as gratifications. This also happens when they are using social networking websites. The uses and gratifications approach is therefore a good way to find out what other purpose students use social media platform for country's CoE. From a uses and gratifications perspective, social networking sites have a wide range of information material, thus those who utilize their services and resources should be able to satisfy a wide array of needs (Uwem et.al:2013).

Ahn discusses in her research a theory called 'Signalling Theory', and 'Technological Determinism' this theory refers to how individuals on social network sites present themselves, and develop their identities and build trust with others. This means inventions in technology invariably cause cultural change. Put another way, the modes of communication shape human existence. Ahn adds that, by having many friends on the different platforms, this causes the individual to lose the trust of their friends because they start adding people they do not know, to show others how popular they are (Ahn, 2011b).

Pardo believes that technology offers a platform for innovation, and allows its users to express their opinions about how they feel towards the information being published. He adds that, social media is also a platform that allows students to interact with one another, with their teachers and communities that share their same education therefore making ICTs 'mobility multiplier' Schramm (1976), Lerner (1958) cited in Tuurosong., Kendie and Agbesinyale (2010, p.1). Pardo again states that these types of interactivity are "an essential part of how humans learn", (Pardo, 2013, p. 45).

Kirschner \& Karpinski, discuss Wim Veen's new term, "Homo Zappiens", which refers to the learners of the new generation, and the new way they use to learn. This new way is known as "meta-cognitive skills," meaning they learn on their own without the need for instructions, it is also called "discover-based learning." They also added that, the younger generation shares a unclear bond with technology since their birth, leading them to multi-task. They note that $46 \%$ of the younger generation who access the internet use it to help them with their school assignments (Kirschner and Karpinski, 2010).

\subsection{Methodology}

This exploratory research utilized both qualitative approaches to address the research questions. The questionnaire was distributed to tutors to produce data for analysis in order to describe the current integration of ICTs into teaching in the Colleges of Education in Ghana.

\subsection{Research Instruments}

The instruments that were employed to gather the data were focus groups interview, questionnaire, extensive classroom observation, and documentary review to gather data. The use of multiple methodologies permitted 
triangulation of the data to improve the validity of the findings, and enable greater inferences from the results.

\subsection{Data Analysis Plan}

Data from the questionnaire (quantitative) were analyzed using SPSS. The data were used in answering the research question one. As needed, frequency counts and valid per cents were obtained. In the analysis, the Likert categories of strongly agree (5) and agree (4) as well as categories of strongly disagree (1), disagree (2), and undecided (3) were collapsed. In other words, categories of agree and strongly agree were combined and a score of (1) was assigned to all agree/strongly disagree responses.

\subsection{Population, Sample and Technique}

The accessible population available for this research included tutors of Peki College of Education, Peki and the St Francis College of Education, Hohoe, St Theresa's College of Education, Hohoe, Amedzofe College of Education, Amedzofe, Dambai College of Education, Dambai, Jasikan College of Education, Jasikan and Akatsi College of Education, Akatsi. A total of one hundred and twenty respondents were contracted for the research through a purposive sampling technique thirty-six of the respondents were used consisting both twenty (20) males, sixteen (16) females found in the vocational skills department.

$$
\frac{\mathrm{N}}{1+\mathrm{N}(\alpha)^{2}}
$$

The formula $\mathrm{n}=$ was used in determining the sampling size for the study; where $\mathrm{n}=$ sample size, $\mathrm{N}=$ total population of the study area, $\alpha$ is the confidence level (which is 95 per cent).

From the interpolation, a sample size of 36 tutors was obtained for the study. Again, the use of the Napierian Log was used to verify the reliability and also to validate the sample the sample size obtained. The formula $\left(1+\mathrm{n}^{-1}\right)^{\mathrm{n}}=2.7183$ where $\mathrm{n}$ the sample size used.

\subsection{Discussion of Findings}

The discussion has been organized into sub-sections to reflect the key issues identified in the literature. This has been done within the bounds of addressing each research question.

\subsection{How do current approaches to ICT in the Colleges of Education make ICTs a catalyst for transformation in the teaching and learning process?}

\section{The Tutors}

Feedback from students on tutor activities carried out is necessary to facilitate improvement on the outcome. In item one from table $1.26(72.2 \%)$ of the respondents felt the outcome provided by tutors was ideal. However, $10(27.7 \%)$ of the respondents lamented that tutors did not provide feedback on their progress in the courses (FVA 111, FVA 221 and FVA 222). Diploma in Basic Education is awarded based on cumulative grade point from continuous assessment scores from one assignment and one quiz and end of semester examination organized by the Institute of Education University of Cape Coast based on the performance of the candidate. Failure to provide early and prompt feedback will blur the aspirations and focus of the students. Tutors were then urged to make available the necessary academic information on students early enough to help them improve on their worth. Again, certain objectives were stated.

The aim was to inquire if tutors had actually acquired the facts, the knowledge, the skills, the attitude, the beliefs and the values that were intended. It was also done to find out whether the selected content contributed effectively; whether the integration of experience and content were effective. Other such important issues would be established under the evaluation. Wheeler (1967) postulate that theory can be strengthened and practised more effectively if this sort of thorough going evaluation is pursued. The fundamental purpose of curriculum development is to ensure that students receive integrated, coherent learning experiences that contribute towards their personal, academic and professional development. $88.8 \%$ of the respondents forming the majority, gave the indication that the use of ICTs (SNS) has made it easy for students to assess course objectives which were clearly explained to them while $11 \%$ felt the course objectives were not explained, just because they are digital migrants. All questionnaire sought information on the general view of all the courses offered and not the individual courses taught. This means that the failure of one or two tutors to clearly explain the course objective to students may affect students' perception, interpretation and judgement. With reference to tutors emphasizing important point in the course of teaching, majority $(94.4 \%)$ as opposed to the minority $(5.5 \%)$ of the respondents agreed that they placed emphasis on important points. This meant that the very core of each course was stretched for the understanding of the students by tutors. Tutors were supposed to apply the knowlegde gained in their future lives. Item 3 in table 1 which sought to inquire if the relevance of each course of study was laid bare, produced a response where majority $(82 . \%$ ) as against $14.7 \%$ of the respondents agreed that as the course progressed, the tutors said they show how each topic fit into the course as a whole. The data illustrate the 
respondents' awareness of how each of the topics fits into the main course. In item 4 of table 1, the focus was to inquire whether there was a close agreement between the stated course objectives and what was actually taught. Eleven of the respondents representing 30.5\% answered in the negative whiles twenty-five $(69.4 \%)$ felt the colleagues were able to meet their stated objectives in the course outline. What is gathered was that the tutors had the privilege to develop plan in line with course content for each semester aligning it to the National Teaching Standards (NTS) of Ghana. Again the questionnaire was meant to assess some specific activities of the tutors that contribute to the success of the programme or otherwise. The respondents were requested to assess their own performance as tutors. $9(25 \%)$ of the respondents were of the view that they were not good whereas majority $27(75 \%)$ agreed that they were good. The pre-vocational skill (art related) programme in Ghana is considered a teacher training programme. In view of this, it is imperative that tutors are positioned to give out their best. The slightest insinuation on the integrity of the tutors should be of great concern.

Likert scale ranging from strongly disagree (SD) coded as 1 to strongly agree (SA) coded as 5 . The results on the opinions of tutors about the integration of ICTs in the teaching and learning in colleges of education are presented in Table 1.

Table 1: Descriptive Statistics of Tutors opinion on how the integration of ICTs has improve teaching and learning in the Colleges of Education.

\begin{tabular}{|c|c|c|c|c|c|}
\hline Questionnaire Items & SD(1) & $D(2)$ & $\mathbf{N}(3)$ & $\mathbf{A}(4)$ & $\mathbf{S A}(5)$ \\
\hline $\begin{array}{l}\text { 1. How do current approaches to ICT in the Colleges of Education } \\
\text { make ICTs a catalyst for transformation in the teaching and learning } \\
\text { process? } \\
\text { ? }\end{array}$ & $0 \%$ & $10 \%$ & $0 \%$ & $0 \%$ & $72 \%$ \\
\hline $\begin{array}{l}\text { 2. Has the use of ICTs influenced your teaching and learning } \\
\text { process? }\end{array}$ & $0 \%$ & $0 \%$ & $0 \%$ & $11 \%$ & $88 \%$ \\
\hline $\begin{array}{l}\text { 3. Do you (tutor) incorporate } 21 \text { st century teaching and learning skills } \\
\text { in the course of teaching? } \\
\text { ? }\end{array}$ & $0 \%$ & $0 \%$ & $3.3 \%$ & $14.7 \%$ & $82.0 \%$ \\
\hline $\begin{array}{l}\text { 4. Did you achieve your course objective when you integrated } \\
\text { ICTs in your teaching and learning? }\end{array}$ & $0 \%$ & $0 \%$ & $0 \%$ & $30.5 \%$ & $69.4 \%$ \\
\hline $\begin{array}{l}\text { 5. Do you believe that implementing the use of ICTs in the } \\
\text { educational process will increase communication between } \\
\text { teachers and students? }\end{array}$ & $0 \%$ & $0 \%$ & $11 \%$ & $11 \%$ & $78 \%$ \\
\hline $\begin{array}{l}\text { 6. Do you think there is enough technical Support for the } \\
\text { integrated ICTs in your teaching and learning? }\end{array}$ & $0 \%$ & $0 \%$ & $0 \%$ & $20 \%$ & $80 \%$ \\
\hline $\begin{array}{l}\text { 7. Do you help students to develop specific } \\
\text { practical skills needed by professionals } \\
\text { in the field related to art education? }\end{array}$ & $0 \%$ & $0 \%$ & $9 \%$ & $11 \%$ & $80 \%$ \\
\hline
\end{tabular}
Field study, 2019

\subsection{Tutors Qualification}

From the documentary review, focus group interview, and observations, tutors have varying academic qualifications. From the documents, it was realised that six of the tutors sampled held M.Phil. Degrees in art and culture, fourteen respondents listed themselves as having master's degree in art education, ten of the respondents are pursing MA and M.Phil. at KNUST and University of Education, Winneba respectively, the other six said that they were okay with their first degree and that age would not allow them to go for a second degree. When asked whether they would describe themselves primarily as arts educators or other, all six (6) respondents identified themselves as "art educators". It was observed that out of the six tutors who had had M.Phil. Degrees in art, only five had professional training as teachers, within the thirty, more have had professional training before going for further studies. This indicated that majority of the tutors were of tutor's status. Tutors and all academics need to renew their seriousness about teaching, learning and more importantly, research. When tutors were to indicate the level at which students participated in class discussions, five of the respondent said that the level of students' participation is satisfactory. By this, twenty-two forming majority said that they allowed their students to participate in the lessons they teach and the students had the opportunity to ask for clarification or explanations on issues that they find difficult to comprehend. This supports the position of (Henard (2010) who noted that unlike the secondary school, higher education students are expected to gain an academic background, and become professional reflexive and socially responsive. When tutors were asked whether the "Art Related" and the taught at the colleges in only the semester are evaluated based on a criterion and whether criterion used was as fair as possible, majority of the respondents as against the minority felt their evaluation methods were satisfactory and good or excellent. By this, tutors use evaluation that were fair in all respects. The research 
measured a critical component of the assessment of Art in Colleges of Education-teaching. It is therefore imperative that tutors employed to teach must have command over the subject they teach. Regarding the issue of knowlegde base of tutors on the course they teach and to also triangulate the responses received from some sampled students on the same issue, most of the tutors' responses revealed that they had sufficient and thorough in-depth knowledge over courses they teach. However, at first year first semester, Art Related curriculum, responses revealed that some tutors were handling courses which either-to were not in their area of speciality. This might have accounted for the reasons why minority of the respondents felt that their knowledge to teach course assigned them was sufficient. This notwithstanding, the responses further indicated that tutors employed to teach the art in colleges had sufficient knowledge in the Art they teach. This substantiates that of Fraenkel and Wallen (2000) who opine that the successful lecturer is one who knows thoroughly what he or she is teaching and those whom he or she is teaching and has the ability to link the two through a mastery of communication. It is not enough to have the knowledge without adequate and appropriate means of transferring this knowledge. The conclusive result of decades of research on knowledge base is that what a person already knows largely determines what new information he attends to, how he organizes and presents new information, and how he filters new experiences, and even what he determines to be important or relevant (Alexander and Murphy, 2000 cited in Duku 2012). This tutors need to exhibit sufficient knowledge of teaching methods and select appropriate methods of teaching contents. In this purview, Art Education curriculum in Colleges of Education stood to gain from tutors who not only know the content of the course they teach but had control over integrating ICTs in the teaching methods they use. In spite of the outcome from the above, some sampled students interviewed agreed that tutors stimulate their interest in the subject. Such encouragements should be reinforced so that many students would see the need to learn. That notwithstanding they proposed that tutors should adopt the constructivist approach to teaching and learning (Grennon and Martin, 1999).

\subsection{Do you (tutor) incorporate 21st century teaching and learning skills in the course of teaching?}

Art Education in Ghana encourages the students to ask questions and be inquisitive. The tutor is seen as a facilitator and guide, rather than as the main source of knowledge. This approach, therefore, supports the $21 \mathrm{st}$ century learning skills where the role of the teacher has changed from being entrusted with the "transmission of knowledge to supporting and guiding self-regulated student learning' (Van Eekelen, Boshuizen and Vermunt, 2005 cited in Duku 2012). Amenuke (1999) states several teaching techniques are used in Ghanaian Art Education, but the choice of any technique depends on the nature of the aspect being taught; Its content, resources and the situation in which the teaching is being done. In Art education, practice based from teaching is preferred to lecture and any form of technique that calls for subject memorization of facts should, therefore, be avoided. The use of information technology (IT) teaching resources featured in the items for respondents to react to. It was realised that although the sampled Colleges of Education have only one IT resource available for teaching, which is under the auspices of the mathematics and ICT departments in the Colleges, with a few liquid crystal display (LCD) projectors majority $(88.8 \%)$ of the sampled tutors had their own ICT tool which they use in teaching, only few of the tutors having the phobia of handling the tools in ICT do not visit the facility.

Arko-Cobbah (2004) cited in Duku (2012) refers to the central role of information and communication technology (ICT) as a 'central component of the learning process, especially when it comes to students centered learning'. Technology therefore, can be used both inside, to help tutors in creating an interactive classroom environment, as well as outside the classroom, in order to enhance students' learning processes and complement what is learnt in a classroom setting. This can empower students to access information and analyse it critically in their own time and space. It can also prove to be a highly useful component in designing professional development programmes, as proposed by (Lavoie and Rosman 2007).

In UNESCO (2002) studies of information and communication technology development in both developed and developing countries, they identified at least four broad approaches through which educational systems and individual schools proceed in their adoption and use of information and communication technologies. These four approaches are termed emerging, applying, infusing and transforming.

The study further revealed that colleges at the beginning stage of information and communication technology development demonstrate the emerging approach. Such colleges begin to purchase, or have had donated, some computing equipment and software. In this initial phase, administrators and tutors are just starting to explore the possibilities and consequences of using ICT for school management and adding ICT to the curriculum. It was evident that colleges at this emerging phase were still firmly grounded in traditional, teachercentered practice. The curriculum reflects an increase in basic skills but there was an awareness of users of ICT. This is reflective of the practice and paradigm orientation of all seven colleges of education under this study. It was observed that tutors do no only use LCD projector in class but also make use of the virtual classrooms such as "google classroom and Edmondo classroom" alongside their tablets, IPad and telephones out of class to connect with students and provide assess. This is inline with "Needs and Gratifications Theory" Severin \& Tankard (2001). The study further confirms that many tutors are using the plethora multimedia presentations in 
class and online forums and chats, along with e-mail access, and course websites for achieving readings and display students' work. This means that tutors have employed technology to their advantage in making sure that students understood the concept they imparted and by the appropriate means. The analysis indicates that majority respondents agreed with that of the thirty-six, thirty tutors use variety of teaching methods while the few, minority of tutors did not observe such variation.

It could therefore, be concluded that many tutors in the colleges varied their teaching methods by integrating it with the numerous ICTs to suit the particular lessons and students. Some of the data derived from the course outlines to triangulate this fact listed some teaching strategies adopted by the tutors as demonstration, lecture, project work, field trip, discussions and the use of resource persons. The variety of teaching methods made it possible for the majority to use an appropriate method to send their messages across to the students which is reflective to performances of the students' results at the end of every semester. Tutors emphasised that they did that because their students would invariably be teaching the future generation and as such strong foundation needed to be built. This supports the view that teachers should embrace the "new paradigm" of professional development which has moved away from short-term teacher training events where information is transmitted by an expert to a group of attentive listeners to a more constructive model (Lind, 2007). The TPACK Model is based on recognition that learning takes place overtime and that active learning requires opportunities to link previous knowledge with new understanding (Upitis, 2005). Also, this new approach to teaching is being fostered by T-TEL (Transforming Teacher Education and Learning) throughout all the colleges of education. This is a Ghana government programme to support the implementation of the new policy framework for PreTertiary Professional Development and Management. Nilson (2010) ascertains that in the course of building knowlegde of the effectiveness of different teaching formats and methods, lecturers apparently run out of excuses for relying on traditional lecture.

\subsection{Do you help students to develop specific practical skills needed by professionals in the field related to art education?}

On the issues of provision of adequate opportunity for questions and discussions during class time and out of class time, it was observed that there were adequate opportunities made for questions and discussions. Theories of learning that highlight the roles of active engagement and social interactions in the students' own construction of knowledge (Bruner, 1966; Kafai \& Resnick, 1996; Piaget, 1963; Vygotsky 1978) strongly support this student-centered paradigm. Learning is an interactive and social process. Many environmental factors including how the instructors teach, and how actively students are engaged in the learning process, positively or negatively influence how much and what student learn (Lambert \& McCombs, 2000). Students had the opportunity of questioning any difficulty encountered during their study. This helps in broadening their scope, perception and understanding of art education as a course of study which helps in the acquisition of practical skills. Majority of students interviewed agreed that the tutor encourage independent thinking. This implies there is the respect for the individual's independence in the course. The study observed that each student is encouraged to be him or herself. In art education curriculum, independence of students fosters creativity. Students have the opportunity to freely express themselves and exhibit their innate creativity including contributing meaningfully to the study. Art as a language of symbols tends to dwell much on the use of signs and symbols. It is therefore, imperative that tutors in the colleges make use of teaching aid to give a concrete understanding to courses of abstract nature. Observations used confirmed that tutors used effective teaching aids or methods. In training students in Art Education, the trainees must not only observe their tutors use the teaching aids; they must have the opportunity to make and use their teaching aids where appropriate. The effectiveness is not concerned with any particular teaching method but rather, it is concerned, in a more general sense, with the way in which tutors operate in their classrooms, the decisions they make, the actions they take, their interaction with the students, their presentation skills, and the way they manage the group (Nilson 2010). Notwithstanding the fact that art education curriculum is designed to train art teachers for various levels of our national institutions, majority of students interviewed, agreed that the lecturers helped students to develop specific practical skills needed by professionals in the fields related to the course. This meant that the students had assistance in developing their skills in the various art subjects through the practical components of the courses offered. The general complaint among students when quality work was demanded, however, was that lecturers created the stress for them by being too demanding. Lecturers teaching the undergraduates should seriously encourage and even coerce students to learn, to be interested in knowledge and be critical in their learning, and not just teach students to learn facts.

\subsection{Conclusion}

The study examined how tutors in the colleges of education integrate ICTs in teaching and learning. Ostensibly, many tutors in the colleges of education in Ghana have access and heavily use ICTs in their teaching. In teaching Art Education, the literature portrays a swing in favour of students because besides the face-to-face meetings with tutors they equally have a plethora assess to connect and be connected to with each other which 
outweigh that of the teacher-centered to disseminating knowledge. The introduction of ICTs such as the TPACK Model, therefore, supports the 21st century learning skills where the role of the teacher has changed from the point of conserving knowledge by transmitting them to succeeding generations to a standard where tutors are challenged to redefine knowledge, test new approaches, and to improve school through organisational changes. ICT usage has become very useful at the fundamental level or emerging phase where limitless ICT provisions are available. The responses further indicated that tutors employed to teach the Art Education courses had sufficient know-how of the use of ICTs to actualize what is taught. ICTs gives both tutors and students the opportunity of interactivity at any time.

\subsection{Suggested area for Further Research}

Even though the scope of technological influences on contemporary teaching are very broad, the study was limited to how ICTs has affected contemporary teaching in the Colleges of Education in Ghana. It is obvious from the study that there are other vital areas of the genre that could not be tackled. These include: the role of digital natives versus migrants in the professional development of tutors in Ghana, the technological influences on the management system in institutions, technology regimes in Ghana and others. The researchers would therefore suggest that these areas of the integrating ICT and ICTs be researched into by other researchers to complement the documentation of the new media in the country

\section{REFERENCES}

Ahn, J. (2011b). The Effect of Social Network Sites on Adolescents' Social and Academic Development: Current Theories and Controversies. Journal of the American Society for Information Science and Technology, 62(8) 1435 445. http://dx.doi.org/10.1002/asi.21540

Alexander, P., \& Murphy, P. (2000). The research base for APA's learner - centered psychological principles. In N. Lambert, \& B. McCombs (Eds.). How students learn (pp. 25-60). Washington, D.D.: American Psychological Association.

Al-rahmi, W. \& Othman, M. (2013). The Impact of Social Media use on Academic Performance among university students: A Pilot Study. In Journal of information systems research and innovation http://seminar.utmspace. edu. my/jisri.

Amenuke, S. K. (1999). Methods of teaching Art. (Unpublished). Kwame Nkrumah Universit of Science and Technology, Kumasi.

Arko-Cobbah, A. (2004). The role of libraries in students - centered learning: the case of students from the disadvantaged communities in South Africa. The International Information and Library Review, 36, pp. 263-271

Attard, A. (2010). Student-Centered learning - toolkit for students, staff and higher education institutions. Brussels: October 2010

Baird, D. Fisher, M. (2005) Neomillennial user experience strategies: Utilizing social networking media to support "always on" learning styles Journal of Educational Technology Systems Journal of Educational Technology Systems 34 (1) 5 - 32

Barber, M. (2007). Reassessing pedagogy in a fast forward age. International Journal of learning, 13, $143-149$.

Bless, C. \& Highson-Smith, C. (2000). Fundamentals of social research methods: An African perspective. Cape Town: Juta Education Pty Ltd.

Bligh, B. (2000). What's the use of lectures? San Francisco: Jossey-Bass.

Bloom, B. (1956). Taxonomy of education objective: the classification of educational goals. Vol. 1: Coginitive domain. New York: Mckay

Bok, D. C. (2006). Our underachieving colleges. Princeton, NJ: Princeton University Press.

Boyd, D. M. \& Ellison, N. B. (2007). Social Network Sites: Definition, History, and Scholarship. Journal of Computer-Mediated Communication, 13(1), 210-230

Boyd, D. (2010) Taken Out of Context: American Teen Sociality in Networked Publics Berkeley, CA: Uniiversity of California; 2008. Available at: www.danah.org/papers/TakenOutOfContext.pdf. Accessed January 16, 2019 Asur, S. \&.

Bradley, P-2009 Whither Twitter? Community College Week, 21(19), 6-8 $<$ http://wwwccweekccweekcom/news/articlefiles/1090-CCW051809-Allpagespdf>

Bruner. J. (1966). Toward a theory of instruction. Cambridge, MA: Harvard University Press.

Burns, N., \& Grove, S. K. (2010).Understanding nursing research: Building an evidence-based practice. Elsevier Health Sciences.

Egedegbe, N. (2013). The Effect of Social Networking Sites on Students' Academic Performance in Girne American University, North Cyprus.

Fraenkel, J. R., \& Wallen, N. E. (2000). How to design and evaluate research in education. (4th Ed). New York: McGraw-Hill. Huberman. 
Hibbison, E. (2011). A learning paradigm. Retrieved from http://vccslitoline.cc.va.us/mrcte/

Kafai, Y., \& Resnick, L. M. (1996). Constructionism in practice. Mahwah, New Jersey: Lawrence Erlbaum Associates.

Karpinski A (2009). A description of Facebook use and academic performance among undergraduate and graduate students. Annual Meeting of the American Educational Research Association, San Diego, Calif.

Kirschner, P., \& Aryn, K. (2010). Facebook ${ }^{\circledR}$ and Academic Performance. Computers in Human Behavior, 26(6), 1237-245. http://dx.doi.org/10.1016/j.chb.2010.03.024

Lambert, N., \& McCombs, B. (2000). Introduction: Learner-Centered school and classrooms as a direction for reform. In N. Lambert, \& B. McCombs (Eds.), How students learn (pp. 1-15). Washington D.C.: American Psychological Association.

Miles, M. B. \& Huberman, A. M. (1994). Qualitative data analysis (2nd ed.). Thousand Oaks, CA: Sage. National Board for Professional Teaching Standards (1998). Washington DC. Retrived November, 92018 from http://www.intime.uni.edu/model/teacher/pedagogysummary.html

Nilson, L. B. (2010). Teaching at its best: A research-based resource for college instructors. ( ${ }^{\text {rd }}$ Ed.). San Francisco, CA: Jossey-Bass.

Ross, M. \& Opoku Asare, N. A. (2009). Addressing key educational issues through art in Ghana. Retrieved from http://www.insea.org/docs.InSENewaletter2-2.pdf

UNESCO (2002). Information and communication technology in education: a curriculum for school and programme of teacher development. Paris: Division of Higher Education.

Upitis, R. (2005). Experiences of artists and artist-teachers involved in teacher professional development programs. International Journal of Education and Arts. 6(8). Retrieved form http://ijea.asu.edu/v6n8/.

Uwem, A. Enobong, A. \& Nsikan, S. (2013). Uses and gratifications of social networking websites among youths in Uyo, Nigeria. 